\title{
Immigration in Canada: Global and Transnational Perspectives
}

\author{
by Alan B. Simmons \\ Toronto: Canadian Scholars' Press 2010 \\ ISBN 978-1-55130-362-8 \\ Softcover, $\$ 49.95$, viii +311 pp.
}

\author{
Reviewed by James C. Saku \\ Frostburg State University (Frostburg, MD) \\ jsaku@frostburg.edu
}

Migration is an important process in regional and global population redistribution. Newbold (2010:126) defines migration as "a change of usual residence by a person, family, or household." While internal migration involves the relocation of people within the same country, international migration involves the movement of people across national boundaries. International migration has generated more debate among policy analysts and academicians. The 1990s immigration liberalization in Canada changed the social and cultural fabric of Canadian society. In Immigration and Canada: Global and Transnational Perspectives, the author presents an elaborate and comprehensive analysis of transnational migration. He notes that apart from racial and ethnic conflicts, transnational migration has created problems including resettlement, adequate financial compensation, and integration of new immigrants into the Canadian society.

Comprising eleven chapters, the book is skillfully written by a seasoned author on immigration in Canada. Chapter one outlines competing perspectives on the definition of Canadian immigration. Simmons identifies and outlines three contrasting perspectives on Canadian immigration. While the first perspective considers Canadian immigration within the framework of policy, the second perspective focuses on the impact of immigration on Canadian cultural and political development. The third perspective examines Canadian immigration within the framework of political, economic, and cultural process of global and transnational forces. This chapter provides a strong foundation for subsequent chapters.

Chapter two focuses exclusively on the theories and implications of international migration on Canada. Simmons addresses the theoretical basis of migration, the process of international migration, and the impact of immigrant settlements on native-born Canadians. While the author acknowledges serious problems in formulating a universal theory on migration, three theories - including push-pull factors, migrant motivation, and border crossing and transitional migration systems — are proposed. Like in most social science disciplines, formulating a universally acceptable theory on international migration is extremely difficult. Nevertheless, the chapter provides an important theoretical framework for subsequent chapters.

The next two chapters examine the historic changes in Canadian immigration policies. According to the author, Canadian immigration policies prior to World War I were designed to attract immigrants from Great Britain, the United States, and northern Europe. The Canadian government initiated policies to entice farmers with financial resources, and farm labourers, to migrate into Canada. There was a substantial change to the source region in the 1960s, because of the decline in European immigrants and anti-racist sentiments towards non-Caucasian immigrants. As a result, several multicultural immigrant policies were proposed and implemented in 1971 and 1988 to attract immigrants from other countries.

Country of origin and factors responsible for the selection of new immigrants to Canada are the focus of the next two chapters. While chapter 5 outlines the criteria used to determine the number of immigrants admitted in each immigrant class, chapter 6 focuses on the national and ethnic origins of immigrants. Based on the selection criteria, Canadian immigrants are classified into economic, family, refugees, and others. In 2005, a large proportion 
of immigrants to Canada were economic (56.6\%), followed by family (24.2\%), refugees (13.6\%), and others $(5.7 \%)$. The origin of international immigrants to Canada has changed tremendously from European to Asian immigrants, who account for about $56.8 \%$.

The next three chapters focus on problems associated with a highly diversified immigrant population. Simmons identified employment and remuneration, socio-cultural integration, and ethnic identity and relationships as the major problems confronting Canadians in coping with immigrants. Even though the official Canadian immigration policy is to promote economic, cultural, and ethnic integration, new immigrants are confronted with inherent problems. For example, immigrants with comparable skills and experience earn lower income than their white Canadian counterparts. Similarly, complete integration of immigrants into Canadian society has not been achieved because of dual national allegiance and complex identities associated with the new immigrants.

Chapter 10 examines the impact of demographic changes on immigration and labour policies. Similar to most western industrialized countries, Canada is experiencing a population decline because of low fertility rates and an increasing number of senior citizens. In addition to international migration, Simmons suggests that tough political policies and funding can alleviate the problem.

Chapter 11 concludes the book with an assessment of future Canadian immigration policies. The author indicates that there are often different perspectives on whether there should be a change on policy reforms. Overall, eight policy initiatives are recommended. They include (1) attract a large number of skilled immigrants and their families; (2) expand migrant worker programs for growing sectors; (3) diversify the entry avenues for immigrants for greater flexibility; (4) reduce the cost of immigrant admission and settlement; (5) encourage the settlement of immigrants in small towns; (6) enforce border controls and deport illegal immigrants; (7) change citizenship rules to reduce undesired costs to the state; and (8) promote immigration to the Canadian public.

The book is an excellent addition to the literature on Canadian immigration. Several important historic and contemporary issues on international migration in Canada are identified and analyzed. The book is well structured and provides a comprehensive understanding of issues on international migration. Professors, students, and policy analysts of international migration will find the book extremely useful. It is written without disciplinary jargon and is therefore readable by scholars from different disciplines.

Notwithstanding the important contributions of the book, the author failed to address the issue of illegal immigration into Canada. Like many developed countries, Canada is confronted with an influx of illegal immigrants. With worsening economic conditions in several African and Asian countries, there has been an increase in the number of illegal immigrants entering Europe, Canada, and the United States. Most importantly, illegal immigration between Canada and the United States is one of the cross-border problems confronting the two countries. Both countries are exploring common solutions to the problem.

\section{References}

Newbold, K.B. 2010. Population Geography: Tools and Issues. Lanham, MD: Rowman \& Littlefield. 